\title{
Peningkatan Keaktifan Belajar Matematika Kelas VI SD Pada Materi Operasi Hitung Bilangan Bulat Melalui Model Pembelajaran Kooperatif Tipe STAD
}

\section{Dewi Setiyaningrum}

\author{
SD Negeri Bumiayu 02 \\ dewisetiyaningrum35@gmail.com
}

\section{Article History}

received 3/12/2020

\begin{abstract}
Less effective and innovative learning models are the factors causing the low activeness of learning mathematics. This study aims to increase the activeness of learning mathematics in sixth grade elementary school students on the material of integer arithmetic operations through the STAD type cooperative learning model. This type of research is Classroom Action Research (CAR). The research was conducted in two cycles. Data collection techniques: observation, test, documentation and field notes. The results showed that the use of the STAD type cooperative learning model was able to increase the activeness of learning mathematics in the class VI integer arithmetic operations material, namely (a) the activity of asking, answering and arguing in the precycle $23 \%$, the first cycle 53\%, and the second cycle $83 \%$.; (b) active discussion in pre-cycle $30 \%$, cycle I 63\%, and cycle II 93\%; and (c) the ability to work on pre-cycle questions $13 \%$, cycle I 43\%, and cycle II 77\%. This study concludes that the STAD type cooperative learning model can increase the activeness of learning mathematics.
\end{abstract}

Keywords: activity, cooperative learning, STAD

\begin{abstract}
Abstrak
Abstrak dalam bahasa Indonesia mengikuti kaidah dalam Pedoman Umum Ejaan Bahasa Indonesia (PUEBI)Model pembelajaran yang kurang efektif dan inoVlatif merupakan faktor penyebab rendahnya keaktifan belajar matematika. Penelitian ini bertujuan untuk meningkatkan keaktifan belajar matematika siswa kelas VI SD pada materi operasi hitung bilangan bulat melalui model pembelajaran kooperatif tipe STAD. Jenis penelitian ini adalah Penelitian Tindakan Kelas (PTK). Penelitian dilakukan dalam dua siklus. Teknik pengumpulan data: observasi, tes, dokumentasi dan catatan lapangan. Hasil penelitian menunjukkan bahwa penggunaan model pembelajaran kooperatif tipe STAD mampu meningkatkan keaktifan belajar matematika pada materi operasi hitung bilangan bulat kelas $\mathrm{VI}$, yaitu (a) keaktifan bertanya,menjawab dan berpendapat pada pra siklus $23 \%$, siklus I $53 \%$, dan siklus II $83 \%$; (b) keaktifan berdiskusi pada pra siklus 30\%, siklus I $63 \%$, dan siklus II $93 \%$; dan (c) kemampuan mengerjakan soal pra siklus $13 \%$, siklus I $43 \%$, dan siklus II $77 \%$. Penelitian ini menyimpulkan bahwa model pembelajaran kooperatif tipe STAD dapat meningkatkan keaktifan belajar matematika.
\end{abstract}

Kata kunci: keaktifan, pembelajaran kooperatif, STAD

Social, Humanities, and Education Studies (SHEs): Conference Series https://jurnal.uns.ac.id/shes

p-ISSN 2620-9284

e-ISSN 2620-9292 


\section{PENDAHULUAN}

Pendidikan di usia sekolah dasar adalah salah satu awal upaya untuk meningkatkan sumber daya manusia yang lebih berkompenten. Pendidikan SD merupakan dasar melanjutkan sekolah berikutnya sehingga perlu dilakukan upaya perubahan peningkatan mutu Pendidikan dalam kelembagaan maupun kegiatan belajar mengajar. Peningkatan mutu pembelajaran khususnya dibidang pendidikan matematika masih rendah. Hal ini terlihat dari proses pembelajaran yang monoton, membosankan, dan tidak menarik karena pembelajaran didominasi oleh guru dan siswa hanya berperan sebagai pendengar dan pencatat atau obyek pembelajaran. Proses pembelajaran ini menyebabkan tingkat keaktifan siswa saat pembelajaran rendah. Selain itu, model pembelajaran kurang inoVlatif dan cenderung membosankan menjadikan kegiatan belajar mengajar kurang bermakna serta mengesankan. Hal tersebut dikarenakan output pembelajaran yang didapatkan bukan dari pemahaman dan penemuannya sendiri.

Keaktifan belajar peserta didik dalam pembelajaran di sekolah yang menunjang keberhasilan proses pembelajaran. Prinsip pembelajaran aktif pada dasarnya merupakan cara belajar dimana siswa terlibat aktif secara utuh, fisik dan mental, sehingga pembelajaran berlangsung secara menarik dan penuh antusias. Strategi pembelajaran yang aktif dalam proses pembelajaran adalah siswa diharapkan aktif terlibat dalam kegiatan pembelajaran untuk berpikir, berinteraksi, berbuat untuk mencoba, menemukan konsep baru atau menghasilkan suatu karya.

Pembelajaran matematika dalam pelaksanaan pendidikan diberikan kepada semua jenjang pendidikan mulai dari sekolah dasar sampai perguruan tinggi. Namun pada kenyataannya tingkat prestasi siswa dalam pembelajaran matematika masih rendah, dikarenakan pada proses pembelajaran matematika seharusnya guru mengerti cara menstimulus siswa agar menyukai dan aktif sehingga dapat memahami materi yang sedang dipelajari.

Proses pembelajaran dikatakan berhasil apabila timbul perubahan tingkah laku pembelajaran yang positif pada siswa sesuai dengan tujuan pembelajaran yang telah direncanakan. Keberhasilan itu dapat dilihat dari tingkat pemahaman, penguasan materi, keaktifan siswa belajar siswa. Semakin tinggi pemahaman, penguasan materi, keaktifan belajar siswa, maka semakin tinggi pula tingkat keberhasilan pembelajaran. Namun dalam kenyataannya, hasil belajar yang dicapai siswa masih rendah.

Tingkat keaktifan belajar matematika pada siswa kelas VI SD Negeri Bumiayu 02 masih kurang dan belum sesuai yang diharapkan, karna faktor pembelajaran yang kovensional, media yang cenderung kurang menarik dan inovatif. Dalam membicarakan materi pengajar lebih menguasai pembelajaran dan peserta didik cenderung pasif dan menjadi pendengar saja, akibatnya peserta didik kurang aktif. Oleh karena itu perlu dilakukan perbaikan pembelajaran.

Proses perbaikan pembelajaran perlu dilakukan agar siswa dapat ikut berperan aktif selama proses pembelajaran berlangsung. Siswa saling bertukar pendapat dalam memahami konsep himpunan serta mampu menyelesaikan soal secara berdiskusi kelompok. Maka diperlukan model pembelajaran yang dapat mengaktifkan siswa selama kegiatan belajar mengajar.

Model pembelajaran kooperatif tipe STAD dapat membuat tingkat keaktifan peserta didik tercapai. Dimana pembelajaran model kooperatif mengutamakan kerja sama untuk mencapai tujuan pembelajaran. Pembelajaran kooperatif merupakan bentuk pembelajaran dengan cara siswa belajar dan bekerja dalam kelompok-kelompok kecil secara kolaboratif dan beroperasi hitung heterogen (Abdul Majid, 2014:174).

Melalui penerapan model pembelajaran kooperatif tipe STAD diharapkan dapat meningkatkan keaktifan belajar siswa. Pembelajaran kooperatif menggunakan sistem pengelompokan yang terdiri empat sampai enam orang yang mempunyai kemampuan 
akademik, jenis kelamin, suku yang heterogen (Wina Sanjaya, 2007:240). Pada proses pembelajarannya siswa diberi kesempatan bekerja dalam kelompok kecil untuk mendiskusikan dan memecahkan masalah. Tugas kelompok dapat memacu para siswa untuk bekerja sama dalam mengintegrasikan pengetahuan baru dengan pengetahuan yang telah dimilikinya. Dalam pembelajaran kooperatif terdapat enam langkah pembelajaran (Ismail, 2003:21) yaitu: a. Menyampaikan tujuan dan memotiVlasi siswa Guru meyampaikan semua tujuan pelajaran yang ingin dicapai pada pelajaran tersebut dan memotiVlasi siswa belajar. b. Menyajikan informasi.

Menurut Ibrahim,dkk (2000: 6) dalam (Abdul Majid, 2014:184) menyatakan bahwa model pembelajarn kooperatif tipe STAD (Student Team AchieVlement DeVlision) dikembangkan pertama kali oleh Robert SlaVlin dan teman-temannya di UniVlersitas John Hopkins, dan merupakan model pembelajaran paling sederhana.

Menurut Abdul Majid (2014 : 185) menyatakan bahwa model pembelajaran kooperatif STAD terdiri atas lima komponen utama, yaitu: 1) presentasi kelas; 2) belajar dengan tim; 3) tes individu; 4) skor pengembangan individu; dan 5) penghargaan tim.

Dari pendapat di atas, dapat ditarik kesimpulan bahwa model pembelajaran kooperatif tipe STAD merupakan model pembelajaran yang sederhana yang memadukan antara beberapa metode yang menekankan pada aktivitas siswa untuk berinteraksi dan saling membantu saat pembelajaran untuk mencapai tujuan yang optimal melalui kerja kelompok.

Berdasarkan uraian diatas rumusan peneliti yaitu: (1) Bagaimana menerapkan model pembelajaran kooperatif tipe STAD dalam meningkatkan keaktifan belajar matematika pada pokok bahasan operasi hitung bilangan bulat di kelas VI semester genap SD Negeri Bumiayu 02 Pati? (2) Apakah model pembelajaran kooperatif tipe STAD dapat meningkatkan keaktifan belajar matematika pada pokok bahasan operasi hitung bilangan bulat di kelas VI semester genap SD Negeri Bumiayu 02 Pati?.

\section{METODE}

Penelitian ini berjenis Penelitian Tindakan Kelas dimana proses penelitian berbentuk siklus yang mengacu pada model Elliot's (Hopkins, 1993), prosedur penelitian dilakukan selama dua siklus. Setiap siklus terdiri dari 4 kegiatan yaitu perencanaan, pelaksanaan, pengamatan, dan refleksi. Subjek penelitian ini adalah siswa dan guru kelas VI SDN Bumiayu 02. Jumlah peserta didik ada 30 anak, yang terdiri dari 12 lakilaki dan 18 perempuan. Teknik pengumpulan data dengan 4 cara yaitu observasi, catatan lapangan, tes dan dokumentasi. Observasi bermanfaat buat mengukur keaktifan siswa sedangkan catatan lapangan bermanfaat untuk mencatat kejadian penting yang sering muncul dalam pembelajaran. Tes dalam penelitian ini digunakan untuk mengukur hasil belajar peserta didik, yaitu berupa soal tes formatif. Dalam menjaga objektifitas proses penelitian ini maka semua kegiatan didokumentasikan dengan alat bantu elektronik kamera berupa foto. Keabsahan data dilakukan dengan Teknik triangulasi Teknik serta Teknik analis datanya mengguanakan analisis kualitatif.

\section{HASIL DAN PEMBAHASAN}

Dalam pelaksanaan kegiatan belajar mengajar yang telah diamati, diperoleh hasil yang mendukung terhadap hipotesis tindakan. Kegiatan yang dilakukan memberikan perubahan kegiatan belajar mengajar pada setiap siklus sehingga mampu menciptakan suasana pembelajaran yang nyaman dan kondusif. Perubahan tersebut, dapat berpengaruh pada tingkat keaktifan siswa dalam pembelajaran matematika pada pokok bahasan operasi hitung bilangan bulat. Hal tersebut diperoleh dari meningkatnya prosentase indikator yang menjadi acuan mengenai keaktifan belajar siswa.

Peningkatan keaktifan belajar siswa terlihat dari: keaktifan siswa dalam bertanya, keaktifan siswa dalam menjawab pertanyaan dari siswa atau guru, keaktifan siswa untuk 
mengemukakan ide atau pendapat, keaktifan siswa dalam kelompok atau berdiskusi, dan kemampuan siswa dalam mengerjakan soal latihan individu maupun kelompok.

Berdasarkan peneliti terdahulu akan penelitiannya mengenai keaktifan belajar siswa dalam pembelajaran matematika pada pokok bahasan operasi hitung-operasi hitung bilangan bulat melalui model pembelajaran kooperatif tipe STAD dengan metode demonstrasi, diantaranya yaitu: penelitian yang dilakukan oleh Zaeni (2010) tentang penerapan pembelajaran kooperatif STAD untuk meningkatkan keterampilan mengurutkan pecahan menyimpulkan bahwa adanya peningkatan keterampilan karena penggunaan model pembelajaran kooperatif STAD yang terlihat dari hasil belajar siswa yang meningkat.

Hal ini terlihat adanya perbaikan pembelajaran matematika kelas VI materi operasi hitung bilangan bulat di SDN Bumiayu 02. Penelitian perbaikan kelas ini diawali dengan kegiatan pembelajara pra siklus, kemudian dilanjutkan dengan pembelajaran siklus I dan siklus II. Hasil penelitian dijelaskan secara detail sebagai berikut:

\section{Siklus Pra siklus}

a. Perencanaan

Pada penelitian tindakan pra siklus, peneliti bersama superVlisor II merencanaan tindakan kelas dengan menyusun rencana pelaksanaan pembelajaran berupa pedoman RPP selama 70 menit (2 jam pelajaran) dengan materi ajar Operasi hitung-Operasi hitung Bilangan Bulat, Lembar soal evaluasi, Lembar penugasan siswa, Lembar soal perbaikan, Lembar soal pengayaan, dan Lembar observasi.

b. Pelaksanaan

Pembelajaran pra siklus dilakukan sesuai dengan jadwal yang telah ditetapkan yaitu hari Senin , 29 Februari 2020 pada pukul 09.00-10.10 dengan jumlah kehadiran 30 anak. Pada pembelajaran prasiklus masih menggunakan metode yang sederhana yaitu dengan metode ceramah pada pokok bahasan operasi hitung-operasi hitung bilangan bulat.

c. Pengamatan atau Pengumpulan Data

Pengamatan proses pembelajaran dilakukan menggunakan lembar pengamatan observasi, berupa aktifitas guru, aktifitas siswa, dan proses pelaksanaan pembelajaran. Pada lembar aktifitas siswa, digunakan untuk mengamati tingkat keaktifan siswa dalam kegiatan belajar mengajar. Diakhir pembelajaran guru mengadakan evaluasi hasil belajar untuk mengetahui tingkat keberhasilan siswa. Berdasarkan hasil pengamatan pada tahap pra siklus, kegiatan pembelajaran belum sesuai dengan harapan dan tujuan pembelajaran yang ingin dicapai guru karena hasil yang diperoleh masih sangat kurang memuaskan. Walaupun pelaksanaan pembelajaran sudah sesuai dengan perangkat pembelajaran yang telah dibuat. Namun, ada beberapa kendala waktu saat kegiatan belajar mengajar dimana waktu yang dibutuhkan guru untuk menyampaikan materi terlalu banyak sehingga melebihi rencana waktu yang ditetapkan. Tahap pembelajaran pra siklus ini dilaksanakan dalam tiga tahap yaitu kegiatan pendahuluan, kegiatan inti, dan penutupan.

Berdasarkan pengamatan tindakan pra siklus diperoleh hasil, yaitu: keaktifan siswa dalam bertanya ,menjawab, dan berpendapat ada 7 anak (23\%), keaktifan siswa dalam kelompok atau berdiskusi 9 anak $(30 \%)$, dan kemampuan siswa dalam mengerjakan soal latihan individu maupun kelompok 4 anak (13\%), sehingga hasil belajar siswa rendah karena belum tercapainya kriteria ketuntasan minimal $(K K M \geq 70)$. Ada sebanyak 7 siswa (23\%) dari siswa di kelas mendapatkan nilai di atas KKM, sedangkan sisanya ada 23 siswa (77\%) yang mendapatkan nilai di bawah KKM. 
d. Refleksi

Pada tahap pembelajaran ini penulis masih cenderung lebih banyak menggunakan metode ceramah walaupun sudah disertai beberapa gambar bilangan bulat. Selama pelaksanaan pembelajaran awal berlangsung, peneliti mengamati permasaalahan yang muncul selama pelaksanaan pembelajaran yaitu siswa jarang untuk bertanya dan menyampaikan pendapat saat kegiatan belajar, kurangnya perhatian siswa dalam pembelajaran, hanya bergantung pada penjelasan guru, pembelajaran masih berpusat pada guru. Hal tersebut karena kurangnya keaktifan belajar siswa pada materi operasi hitung bilangan bulat, sehingga menyebabkan

\section{Siklus I} hasil belajar siswa rendah.

\section{a. Perencanaan}

Peneliti bersama superVlisor II merencanakan perbaikan pembelajaran guna untuk membenahi kekurangan yang ada pada kegiatan belajar pra siklus. Perencanaan perbaikan pembelajaran pada tahap ini, peneliti melakukan penyusunan rencana perbaikan pembelajaran berupa perangkat pembelajaran (RPP Siklus I, Lembar Kerja Siswa, Lembar soal evaluasi, Lembar penugasan siswa, Lembar soal perbaikan, Lembar soal pengayaan, dan Lembar observasi), mengurangi penggunaan metode ceramah dan menambah metode dalam pembelajaran agar siswa terlibat aktif dalam kegiatan pembelajaran, guru juga harus memberikan motiVlasi belajar siswa agar siswa berani mengemukakan pendapatnya maupun menjawab pertanyaan,serta mengelola kelas agar dalam proses pembelajaran kelas menjadi lebih nyaman.

b. Pelaksanaan

Pelakasanaan perbaikan pembelajaran siklus I ini dilaksanakan sesuai dengan jadwal yang telah ditetapkan yaitu Rabu, 16 Maret 2020 pukul 07.00 - 08.10 di SD Negeri Bumiayu 02 kelas VI dengan jumlah siswa yang hadir 30 orang. Dimana, pada siklus ini guru menerapkan model pembelajaran kooperatif tipe STAD pada pokok bahasan operasi hitung bilangan bulat.

c. Pengamatan dan Pengumpulan Data

Pelaksanaan pembelajaran siklus I mengalami peningkatan dari pada tindakan pembelajaran sebelumnya. Pada tahap ini, siswa sudah termotivasi dan tertarik untuk mengikuti pembelajaran karena pada kegiatan pembelajaran guru menggunakan model pembelajaran STAD, sehingga pembelajaran menjadi menarik. Pada pelaksanaan pembelajaran tindakan siklus I terdiri dari tiga kegiatan pembelajaran yaitu: kegiatan pendahuluan, kegiatan inti, dan kegiatan penutup.

Berdasarkan hasil pengamatan siklus I terlihat adanya peningkatan keaktifan belajar siswa dari kondisi aktifitas siswa dan guru dalam kegiatan belajar mengajar yang sudah cukup mengalami peningkatan. Dimana sudah terlihat adanya keaktifan siswa dalam bertanya, menjawab, dan berpendapat ada 16 anak (53\%), keaktifan siswa dalam kelompok atau berdiskusi 19 anak (63\%), dan kemampuan siswa dalam mengerjakan soal latihan individu maupun kelompok 13 anak (43\%), sehingga menyebabkan hasil belajar siswa rendah karena belum tercapainya kriteria ketuntasan minimal (KKM 270). Dimana ada sebanyak 11 siswa (37\%) dari siswa di kelas mendapatkan nilai di atas KKM, sedangkan sisanya ada 19 siswa $(63 \%)$ yang mendapatkan nilai di bawah KKM.

Meskipun hasil peningkatan belum terlihat secara optimal dan sudah cukup baik, maka kriteria keberhasilan perbaikan pembelajaran yang direncanakan dalam penelitian ini dinyatakan berhasil namun belum 
maksimal, karena masih ada beberapa indikator belum tercapai secara optimal, maka guru harus berusaha untuk menuntaskan siswa sesuai yang direncanakan.

d. Refleksi

Hasil refleksi pada siklus I diperoleh beberapa catatan untuk diperbaiki, yaitu: proses pembelajaran sudah berjalan efektif, suasana pembelajaran kurang terkendali saat pembagian kelompok diskusi, pemanfaatan alat peraga dalam menyampaikan materi kurang optimal, perhatian siswa dalam pembelajaran masih belum fokus dan mudah dialihkan, hanya beberapa siswa yang berani untuk menyampaikan pendapat maupun bertanya mengenai materi yang belum dipahami, Kurang adanya kerjasama antara

\section{Siklus II} anggota kelompok dalam kegiatan diskusi.

Pada pembelajaran siklus I, masih terdapat beberapa kekurangan. Oleh karena itu, perlu dilakukan perbaikan pembelajaran pada siklus II. Pada kegiatan pembelajaran siklus II terdapat beberapa tahapan kegiatan yaitu:

a. Perencanaan

Perencanaan pelaksanaan siklus II, diawali dengan menyusun perbaikan perangkat pembelajaran kedua (Rencana Perangkat Pembelajaran Siklus II, Lembar Kerja Siswa, Lembar soal evaluasi, Lembar penugasan siswa, Lembar soal perbaikan, Lembar soal pengayaan, dan Lembar observasi). Sebelum pembelajaran ini dilaksanakan peneliti bersama superVlisor II berdiskusi untuk membenahi kekurangan yang ada pada siklus I, diantaranya: a) siswa pada saat mengerjakan tugas individu masih ada siswa yang saling membantu padahal seharusnya soal itu dikerjakan individu. Maka dari itu, guru harus memotiVlasi lagi siswa supaya siswa percaya diri dengan kemampuannya; b) Guru seharusnya sering memberikan latihan soal supaya hasil pembelajaran semakin meningkat.

b. Pelaksanaan

Kegiatan pembelajaran siklus II dilaksanakan pada hari Senin, 21 Maret 2020 pukul 09.00 - 10.10 dengan menggunakan model pembelajaran STAD pada pokok bahasan operasi hitung bilangan bulat di SD Negeri Bumiayu 02 kelas VI semester II dengan siswa yang hadir sebanyak 30 anak.

c. Pengamatan atau Pengumpulan Data

Kegiatan pembelajaran pada siklus II berlangsung dengan baik. Pada akhir pembelajaran juga diadakan evaluasi hasil belajar siswa untuk mengetahui tingkat keberhasilan siswa sehingga tingkat keaktifan siswa juga mengalami peningkatan. Hal ini terlihat dari hasil evaluasi siswa sudah mencapai KKM (KKM $\geq 70)$ dengan prosentase nilai siswa yang sudah mencapai KKM sebanyak $92 \%$.

Berdasarkan hasil pengamatan dan pengumpulan data pada siklus II ini diperoleh hasil, yaitu: siswa yang aktif dalam bertanya, menjawab, dan berpendapat ada 25 anak (83\%), keaktifan siswa dalam kelompok atau berdiskusi ada 28 anak (93\%), dan kemampuan siswa dalam mengerjakan soal latihan individu maupun kelompok ada 23 anak (77\%) sehingga hasil belajar siswa mengalami peningkatan yang optimal.

Pada siklus II ini, nilai yang ditetapkan oleh peneliti telah mencapai kriteria ketuntasan minimal. Pada saat pembelajaran siklus II ini pembelajaran sudah terpusat pada siswa sehingga siswa aktif dalam pembelajaran dan guru berperan hanya sebagai fasilitator. Oleh karena itu tidak perlu diadakan perbaikan ke siklus selanjutnya.

d. Refleksi 
Hasil refleksi pada siklus II mata pelajaran matematika tidak ditemukan kendala yng berarti dalam kegiatan pembelajaran. pada tindakan kelas siklus II dapat disimpulkan bahwa keaktifan siswa dalam bertanya, menjawab, dan berpendapat ada 25 anak (83\%), keaktifan siswa dalam kelompok atau berdiskusi ada 28 anak (93\%), dan kemampuan siswa dalam mengerjakan soal latihan individu maupun kelompok ada 23 anak (77\%). Dari hasil yang diperoleh diatas maka model pembelajaran kooperatif tipe STAD dapat meningkatkan keaktifan siswa dalam pembelajaran matematika pada pokok bahasan operasi hitung-operasi hitung bilangan bulat sudah mencapai target, maka dari itu pelaksanaan penelitian tindakan kelas cukup sampai siklus II yang berarti tidak perlu dilaksanakan siklus selanjutnya.

Setelah berdiskusi dengan rekan sejawat mengenai hasil belajar mengajar selama dilakukan penelitian diperoleh pendapat bahwa penelitian ini mampu meningkatkan keaktifan siswa. Hal ini berarti setelah dilakukan penelitian, peneliti dapat menyimpulkan apakah penelitian ini menerima atau mendukung hipotesis tindakan.

Berdasarkan data-data yang diperoleh diatas, selama pelaksanaan tindakan perbaikan pembelajaran dari siklus I sampai siklus II terlihat adanaya keaktifan belajar matematika pada materi operasi hitung bilangan bulat di SD Negeri Bumiayu 02 kelas VI dapat disajikan dalam tabel 4.1, sebagai berikut:

Tabel 1. Data Peningkatan Keaktifan Belajar

\begin{tabular}{clccc}
\hline \multirow{2}{*}{ No. } & \multicolumn{2}{c}{ Indikator Pencapaian } & \multirow{2}{*}{ Pra-Siklus } & \multicolumn{2}{c}{ Setelah Tindakan Kelas } \\
Siklus I & Siklus II \\
\hline 1 & Keaktifan siswa dalam bertanya, & 7 siswa & 16 siswa & 25 siswa \\
& menjawab,dan berpendapat & $(23 \%)$ & $(53 \%)$ & $(83 \%)$ \\
2 & keaktifan siswa dalam kelompok & 9 siswa & 19 siswa & 28 siswa \\
& atau berdiskusi & $(30 \%)$ & $(63 \%)$ & $(93 \%)$ \\
3 & kemampuan siswa dalam & 4 siswa & 13 siswa & 23 siswa \\
& mengerjakan soal latihan & $(13 \%)$ & $(43 \%)$ & $(77 \%)$ \\
\hline
\end{tabular}

Melalui hasil penelitian ini menunjukkan bahwa perbaikan pembelajaran melalui model pembelajaran kooperatif tipe STAD memiliki dampak positif dalam meningkatkan keaktifan belajar peserta didik. Pada siklus 2 keaktifan belajar peserta didik tercapai. Menurut hal tersebut maka dapat disimpulkan bahwa hipotesis tindakan mengenai penggunaan model pembelajaran kooperatif tipe STAD mampu meningkatkan keaktifan belajar siswa dalam pembelajaran matematika pokok bahasan operasi hitung bilangan bulat dapat diterima.

\section{SIMPULAN}

Berdasarkan hasil penelitian tindakan kelas di SD Negeri Bumiayu 02 mapel matematika materi operasi hitung bilangan bulat di kelas VI dapat disimpulkan bahwa model pembelajaran kooperatif tipe STAD mapel matematika pada materi operasi hitung bilangan bulat dapat meningkatkan keaktifan belajar siswa. Penggunaan model pembelajaran STAD dalam matematika dapat menambah Vlariasi pembelajaran yang menarik karena dapat mengaktifkan siswa dan mempermudah siswa dalam mengerjakan dan memahami pembelajaran metematika.

$\mathrm{Hal}$ ini terbukti dengan adanya peningkatan keaktifan belajar matematika. Hal ini dapat dilihat dari pencapaian indicator yang diamati, yaitu:

1. Keaktifan siswa dalam bertanya, menjawab dan berpendapat pada pra siklus hanya ada 7 siswa (23\%), pada tindakan kelas siklus I ada 16 siswa (53\%), dan siklus II ada 25 siswa (83\%). 
2. Keaktifan siswa dalam kelompok atau berdiskusi mulai dari sebelum dilakukan tindakan hanya ada 9 siswa $(30 \%)$, pada tindakan kelas siklus I ada 19 siswa (63\%), dan siklus II ada 28 siswa (93\%).

3. Kemampuan siswa dalam mengerjakan soal latihan individu maupun kelompok mulai dari pra siklus hanya ada 4 siswa (13\%), pada tindakan kelas siklus I ada 13 siswa (43\%), dan pada tindakan kelas siklus II ada 23 siswa $(77 \%)$.

\section{DAFTAR PUSTAKA}

Adita, Resa Andre dan Mulyadi. 2017. Peningkatan Keaktifan dan Hasil Belajar IPA Melalui Strategi Team Games Tournament pada Siswa Kelas IV SDN Blangu 1 Tahun Ajaran 2016/2017. Skripsi Program Studi PGSD. Diakses pada 2 Juli 2020. (http://eprints.ums.ac.id/id/eprint/53187)

Aqib, Zainal. 2013. Model-Model, Media, dan Strategi Pembelajaran Kontekstual(InoVlatif). Bandung: Yrama Widya.

Djamarah, Syaiful Bahri dan Aswan Zain. 2010. Strategi Belajar Mengajar. Jakarta: PT.Rineka Cipta.

Idayani, Ni Putu. 2018. "Pengaruh Pembelajaran Kooperatif Model STAD Terhadap Keaktifan dan Hasil Belajar IPA Kelas VII SMP". Jurnal of Education Action Research Vol.2 Number 1. Diakses pada tanggal 14 Juli 2020. (https://ejournal.undiksha.ac.id/index.php/JEAR/artic-le/view/13728)

Iswahyudi,Uut. 2012. " Peningkatan Keaktifan Belajar Matematika Melalui Model Pembelajaran STAD Pada Siswa Kelas III Semester I SDN Bumirejo Kecamatan Juwana Tahun Pelajaran 2012/2013. Skripsi Thesis. UniVlersitas Muhamadiyah Surakarta. Diakses pada tanggal 14 Juli 2020. (http://eprints.ums.ac.id/20964/)

Jumali, Jumali. 2019. "Peningkatan Keaktifan dan Prestasi Belajar IPA Melalui Model Pembelajaran Kooperatif Tipe Student Teams AchiVlement Divisions (STAD) Pada Siswa Kelas V SD Negeri 2 Pandansimping Klaten Tahun Pelajaran 2018/2019". Bachelor (S1) Thesis, UniVlersitas Widya Dharma. Diakses pada tanggal 14 Juli 2020. (http://repository.unwidha.ac.id/1779/)

Majid, Abdul. 2014. Strategi Pembelajaran. Bandung: Remaja Rosdakarya.

Minsih dan Aninda G.D. 2018. Peran Guru dalam Pengelolaan Kelas. Jurnal Profesi Pendidikan Dasar. Vol. 1 Nomor 1, Juli 2020. (https://journal.ums.ac.id/index.php/ppd/article/view/1012/687)

Rahayu, Wiwit Triwik and, Dr. Minsih, S.Ag., M.Pd. (2019). "Peningkatan Keaktifan Dan Hasil Belajar Matematika Siswa Kelas Vla Melalui Pembelajaran Tutor Sebaya Dengan Strategi STAD Di SD Negeri 01 Nangsri Kecamatan Kebakkramat Kabupaten Karanganyar Tahun Pelajaran 2018/2019". Skripsi thesis, UniVlersitas Muhammadiyah Surakarta. Diakses pada tanggal 12 Juli 2020. (http://eprints.ums.ac.id/76425/)

Rattanatumma, Tawachai dan Vichian Puncreobutr. 2016. "Assessing The EffectiVleness of STAD Model and Problem Based Learning In Mathematics Learning Achievement and Problem Solving Ability." Journal of Education and Practice. Vol 7 Nomor 12. Diakses pada tanggal 19 Mei 2020. (https://eric.ed.gov/?id=EJ1099565)

Salo,Eky Setiawan dan Topanus Tulak. 2019. "Penerapan Model Pembelajaran Kooperatif Tipe STAD Untuk Meningkatkan Keaktifan Belajar Matematika Siswa Kelas IV SDN 5 Tikala Kabupaten Toraja Utara". Elementary Journal Vol.2 Nomor 1-Juni 2019. Diakses pada tanggal 12 Juli 2020. (http://journals.ukitoraja.ac.id/index.php/ej/article/view/608)

Sardiman, A. M.. 2012. Interaksi dan Motivasi Belajar Mengajar. Jakarta: Raja Grafindo Persada. 
Sri Anitah W,dkk. 2014. Strategi Pembelajaran Di SD. Tangerang Selatan : UniVlersitas Terbuka.

Sudjana, Nana. 2010. Penilaian Hasil Proses Belajar Mengajar. Bandung: Remaja Rosdakarya

Susanto, Ahmad. 2013. Teori Belajar dan Pembelajaran Di Sekolah Dasar. Jakarta: Kencana Prenada Media Group.

Sutama. 2010. Penelitian Tindakan,Teori dan Praktek dalam PTK,PTS dan PTBK. Semarrang: CV Citra Mandiri Utama.

Suwandi, Sarwiji. 2010. Penelitian Tindakan Kelas (PTK) dan Penulisan Karya IImiah. Surakarta: Yuma Pustaka.

Usman, Mohammad Uzer. 2006. Menjadi Guru Profesional. Bandung: Remaja Rosdakarya

Zaeni. 2010. "Penerapan Pembelajaran Kooperatif STAD Untuk Meningkatkan Keterampilan Mengurutkan Pecahan Pada Siswa Kelas VI SD Negeri Sidakaton 04 Tahun Ajaran 2009/2010". Surakarta : UniVlersitas Negeri Sebelas Maret. 